\title{
PERILAKU MASYARAKAT TERHADAP KEJADIAN DBD DI KECAMATAN CIRACAS JAKARTA TIMUR
}

\author{
Rojali $^{1 凶}$, Awan Putri Amalia ${ }^{1}$ \\ ${ }^{1}$ Jurusan Kesehatan Lingkungan Poltekkes Kemenkes Jakarta 2
}

\begin{tabular}{l}
\hline ARTICLE INFO \\
\hline Article history \\
Submitted : 2020-02-29 \\
Revised : 2020-07-09 \\
Accepted : 2020-07-17 \\
Keywords: \\
DHF \\
Behavior \\
Individual Characteristic \\
Existence of Larvae \\
Water Reservoir
\end{tabular}

\section{Kata Kunci:}

$D B D$

Perilaku

Karakteristik Individu

Keberadaan Jentik

Tempat Penampungan

\begin{abstract}
Dengue Hemorrhagic Fever (DHF) is an infectious disease caused by the dengue virus and transmitted by Aedes aegypti and Aedes albopictus mosquitoes. Increased DHF incidences caused by the unclean lifestyle of people. This study was an analytical study with a cross-sectional approach. The aim was to determine the relationship between individual characteristics, behavior, and environment on the incidence of DHF. Data were collected by interview and observation using a questionnaire and observation sheet. Data analyzed by univariate and bivariate methods with a chi-square analysis test. The number of samples was 107 people with the sampling technique used was simple random sampling. The results showed that $15.9 \%$ of the community had dengue fever in the last six months. There were 4 variables that have a relationship to the incidence of DHF, namely age $(p$-value $=0,000)$, gender $(p$-value $=0.017, O R=4.146)$, knowledge (p-value $=0.034, \mathrm{OR}=5.231)$, actions $(\mathrm{p}$-value $=0.045, \mathrm{OR}=3.740)$, while education $(\mathrm{p}$-value $=0.086)$, work $(\mathrm{p}$-value $=0.748)$, attitude $(\mathrm{p}$-value $=0.078)$, the existence of larvae ( $\mathrm{p}$-value $=0.716$ ) does not have a relationship to the incidence of DHF and 1 variable cannot be connected namely the existence of a water reservoir because $100 \%$ have a water reservoir and 1 variable only looks at the description of DHF events by season.
\end{abstract}

Demam Berdarah Dengue (DBD) adalah penyakit menular yang disebabkan oleh virus dengue dan ditularkan oleh nyamuk Aedes aegypti dan Aedes albopictus. Peningkatan Penyakit DBD ini disebabkan oleh perilaku hidup bersih yang kurang dari Sebagian masyarakat. Penelitian ini merupakan suatu studi analitik dengan metode pendekatan Cross sectional dengan bertujuan untuk mengetahui hubungan antara karakteristik individu, perilaku, dan lingkungan terhadap kejadian DBD. Pengumpulan data dilakukan dengan wawancara dan observasi menggunakan kuesioner dan lembar observasi. Data dianalisis dengan metode univariat dan bivariat dengan uji analisa chisquare. Jumlah sampel dalam penelitian ini adalah 107 masyarakat dengan teknik sampel yang digunakan adalah simple random sampling. Hasil penelitian menunjukkan bahwa $15,9 \%$ masyarakat sakit DBD pada 6 bulan terakhir. Dari 10 variabel terdapat 4 variabel yang memiliki hubungan terhadap kejadian DBD, yaitu umur ( $\mathrm{p}$-value $=$ $0,000)$, jenis kelamin ( $\mathrm{p}$-value $=0,017, \mathrm{OR}=4,146$ ), pengetahuan ( $\mathrm{p}$-value $=0,034$, OR $=5,231)$, tindakan $(\mathrm{p}$-value $=0,045, \mathrm{OR}=3,740)$, sedangkan pendidikan ( $\mathrm{p}$-value $=$ $0,086)$, pekerjaan ( $\mathrm{p}$-value $=0,748)$, sikap ( $\mathrm{p}$-value $=0,078)$, keberadaan jentik (p-value $=0,716$ ) tidak memiliki hubungan terhadap kejadian DBD dan 1 variabel tidak bisa dihubungkan yaitu keberadaan tempat penampungan air karena $100 \%$ memiliki tempat penampungan air serta 1 variabel hanya melihat gambaran kejadian DBD berdasarkan musim.

Corresponding Author:

Rojali

Jurusan Kesehatan Lingkungan Poltekkes Kemenkes Jakarta 2

Telp. 081380120739

Email: rojalijaya@yahoo.com

\section{PENDAHULUAN}

Penyakit Demam Berdarah Dengue (DBD) merupakan penyakit yang disebabkan oleh infeksi virus DEN-1, DEN-2, DEN-3, atau DEN-4 yang ditularkan melalui gigitan nyamuk Aedes aegypti dan Aedes albopictus yang sebelumnya telah terinfeksi oleh virus dengue dari penderita DBD lainya. Keempat tipe virus tersebut telah ditemukan di berbagai daerah di Indonesia dan yang terbanyak adalah tipe 2 dan tipe 3. Penelitian di Indonesia menunjukkan Dengue tipe 3 merupakan serotype virus yang dominan menyebabkan kasus yang berat (Candra, 2010). Nyamuk Aedes aegypti 
menjadi infektif $8-12$ hari sesudah menghisap darah penderita DBD sebelumnya. Nyamuk Aedes aegypti merupakan penyebar penyakit (vektor) DBD yang paling aktif dan utama karena tinggal di sekitar permukiman penduduk. Adapun nyamuk Aedes albopictus, banyak terdapat di daerah perkebunan dan semak-semak (Purnama, 2017).

Sebelum tahun 1970, hanya 9 negara yang menjadi endemi Dengue. Sekarang penyakit ini sudah ada di 100 negara di wilayah WHO Afrika, Amerika, Mediterania Timur, Asia Tenggara, dan Pasifik Barat. Wilayah Amerika, Asia Tenggara, dan Pasifik Barat adalah wilayah yang paling terkena dampaknya. Kasus di seluruh Amerika, Asia Tenggara, dan Pasifik Barat sudah melebihi 1,2 juta di tahun 2008 dan lebih dari 3,2 juta pada tahun 2015 (berdasarkan data resmi yang disampaikan oleh negara-negara anggota). Baru-baru ini jumlah kasus dilaporkan terus bertambah. Pada tahun 2015, 2,35 juta kasus demam berdarah dilaporkan terjadi di Amerika saja, dimana 10.200 kasus didiagnosis sebagai demam berdarah berat yang menyebabkan 1181 kematian (E. Novitasari, 2018).

Terjadinya KLB DBD di Indonesia berhubungan dengan berbagai faktor risiko, yaitu lingkungan yang masih kondusif untuk terjadinya tempat perindukan nyamuk Aedes, pemahaman masyarakat yang masih terbatas mengenai pentingnya pemberantasan sarang nyamuk (PSN) 3M Plus; 3), perluasan daerah endemik akibat perubahan dan manipulasi lingkungan yang terjadi karena urbanisasi dan pembangunan tempat pemukiman baru; serta meningkatnya mobilitas penduduk.

Di Indonesia, demam berdarah pertama kali ditemukan di kota Surabaya pada tahun 1968, dimana sebanyak 58 orang terinfeksi dan 24 orang di antaranya meninggal dunia, dengan angka kematian mencapai $41,3 \%$. Sejak saat itu, penyakit ini menyebar luas ke seluruh Indonesia (Kementerian Kesehatan, 2016). Penyakit DBD dapat muncul sepanjang tahun dan dapat menyerang seluruh kelompok umur. Penyakit ini berkaitan dengan kondisi lingkungan dan perilaku masyarakat (Kementerian Kesehatan RI, 2017). Berdasarkan Profil Kesehatan Indonesia Kementerian Kesehatan RI tahun 2017, Kasus DBD tahun 2017 berjumlah 68.407 kasus, dengan jumlah kematian sebanyak 493 orang.
Jumlah tersebut menurun cukup drastis dari tahun sebelumnya, yaitu sebanyak 204.171 kasus dan jumlah kematian sebanyak 1.598 orang. Angka kesakitan DBD tahun 2017 menurun dibandingkan tahun 2016, yaitu dari 78,85 menjadi 26,10 per 100.000 penduduk. Namun, penurunan case fatality rate (CFR) dari tahun sebelumnya tidak terlalu tinggi, yaitu $0,78 \%$ pada tahun 2016 menjadi $0,72 \%$ pada tahun 2017.

Menurut Badan Meteorologi, Klimatologi dan Geofisika (BMKG) bersama dengan Dinas Kesehatan DKI Jakarta dan Institut Teknologi Bandung (ITB), pada peta prediksi kecocokan iklim untuk DBD Provinsi DKI Jakarta bulan Februari - Maret 2019 menunjukkan angka RH $81 \%$ untuk daerah Jakarta Timur dan angka tersebut dikategorikan tinggi sehingga mendukung pertumbuhan nyamuk Aedes aegypti yang kemudian berakibat pada meningkatnya kejadian DBD (Meteorologi, Geofisika, Nal, \& Sopl, 2019).

Berdasarkan data sekunder Puskesmas Kecamatan Ciracas kasus DBD di Wilayah Kecamatan Ciracas pada tahun 2018 terdapat 204 kasus dan kelurahan yang paling tinggi kasus DBD ada di Kelurahan Ciracas dengan 59 laporan. Pada periode Januari - Maret 2019 kasus DBD di Kecamatan Ciracas didapatkan laporan 156 kasus dan kelurahan yang paling tinggi kasus DBD terdapat di Kelurahan Ciracas sebanyak 50 laporan.

Puskesmas Kecamatan Ciracas melaksanakan kegiatan PSN secara rutin satu minggu sekali. Sejak bulan Januari 2019 PSN 3M Plus dilakukan seminggu 3 kali pada hari Selasa, Jumat, dan Minggu sesuai dari arahan Walikota Jakarta Timur. PSN melibatkan petugas Puskesmas, kader jumantik dan masyarakat. Angka bebas jentik di Kecamatan Ciracas Bulan Januari 2019 yang dilaporkan adalah $90,93 \%$. Angka bebas jentik yang belum mencapai target ABJ Nasional yaitu >95\% menggambarkan padatnya populasi vektor DBD di daerah tersebut yang berkaitan dengan kejadian DBD di Kecamatan Ciracas.

Salah satu yang dapat mempengaruhi peningkatan angka kesakitan serta kematian akibat penyakit ini adalah perilaku masyarakat dalam melaksanakan dan menjaga kebersihan lingkungan. Hal ini terjadi karena kurangnya pengetahuan masyarakat tentang DBD dan kurangnya praktik atau peran masyarakat dalam 
menjaga kebersihan lingkungan sekitar (Litbangkes, 2016).

Masih tingginya kejadian DBD khususnya di wilayah kerja Puskesmas, internal maupun eksternal seperti pengetahuan, sikap, perilaku masyarakat dalam memahami dan melakukan kegiatan kebersihan lingkungan rumah dalam pencegahan kejadian DBD terulang kembali. Dalam meningkatkan pengetahuan masyarakat tentang masalah kesehatan, diperlukan suatu upaya nyata seperti dengan memberikan pendidikan kesehatan.

Berdasarkan latar belakang tersebut di atas, maka penulis akan melakukan penelitian yang bertujuan untuk mengetahui "Berbagai Pengaruh Perilaku Masyarakat Terhadap Kejadian Demam Berdarah Dengue di RW 06 Kelurahan Ciracas, Kecamatan Ciracas, Jakarta Timur Tahun 2019."

\section{METODE PENELITIAN Jenis Penelitian}

Jenis penelitian ini adalah analitik dengan metode Cross Sectional (potong silang) yaitu penelitian untuk mempelajari dinamika korelasi antara faktor-faktor risiko dan efek dengan observasi atau pengumpulan data sekaligus pada suatu saat atau point time approach (BPPSMK Kementerian Kesehatan, 2018).

Faktor risiko adalah faktor-faktor yang mengakibatkan terjadinya efek (pengaruh). Dalam penelitian ini, faktor risiko yang disebut sebagai variabel independen meliputi karakteristik individu, perilaku masyarakat, dan lingkungan. Sedangkan variabel dependen dari penelitian ini adalah kejadian Demam Berdarah Dengue (DBD).

\section{Populasi dan Sampel}

Populasi adalah keseluruhan objek penelitian atau objek yang diteliti. Populasi dalam penelitian ini adalah masyarakat di RW 06 Kelurahan Ciracas, Kecamatan Ciracas, Jakarta Timur yaitu sebanyak 2.674 Kepala Keluarga.

Sampel dalam penelitian ini adalah sebagian masyarakat di RW 06 Kelurahan Ciracas, Kecamatan Ciracas, Jakarta Timur dengan jumlah Rukun Tetangga (RT) sebanyak 13 RT. Jumlah sampel minimum dalam penelitian ini sebanyak 97 responden. Berdasarkan penelitian-penelitian sebelumnya, untuk menghindari drop out atau missing jawaban dari responden maka perlu ditambahkan $10 \%$ dari jumlah sampel yang didapat sehingga jumlah sampel keseluruhan sebesar 107 responden.

\section{Pengumpulan Data}

Data Primer adalah data yang diperoleh dari hasil wawancara dengan menggunakan kuesioner dan hasil observasi atau pengamatan langsung ke lokasi dengan menggunakan checklist. Wawancara menggunakan kuesioner untuk variabel kejadian DBD, karakteristik individu, pengetahuan, sikap dan tindakan. Observasi menggunakan checklist untuk variabel keberadaan tempat penampungan air dan keberadaan jentik nyamuk.

Data sekunder adalah data penunjang untuk melengkapi data primer yang diperoleh dari laporan tahunan dan laporan triwulan Puskesmas Kecamatan, hasil penelitian terdahulu yang berhubungan dengan penelitian, studi kepustakaan, dan data-data lain.

\section{Analisis Data}

Analisis Univariat dalam penelitian ini berupa distribusi frekuensi karakteristik individu meliputi umur, jenis kelamin, pendidikan dan pekerjaan, faktor perilaku meliputi pengetahuan, sikap, dan tindakan, faktor lingkungan meliputi keberadaan tempat penampungan air, keberadaan jentik nyamuk dan gambaran kejadian DBD berdasarkan musim sebagai variabel independen dan distribusi kejadian DBD sebagai variabel dependen.

Dalam penelitian ini variabel yang diuji adalah hubungan antara karakteristik individu meliputi umur, jenis kelamin, pendidikan dan pekerjaan, faktor perilaku meliputi pengetahuan, sikap, dan tindakan, faktor lingkungan meliputi keberadaan tempat penampungan air, dan keberadaan jentik nyamuk terhadap kejadian Demam Berdarah Dengue.

\section{HASIL PENELITIAN \\ Distribusi Frekuensi Kejadian Demam Berdarah Dengue \\ Berdasarkan tabel 1. diketahui bahwa} kejadian DBD dalam kurun waktu 6 bulan terakhir atau dari bulan November 2018 - April 2019 dari 107 masyarakat sebanyak 17 orang $(15,9 \%)$ sakit DBD, dan 90 orang $(84,1 \%)$ tidak sakit DBD. 
Tabel 1. Distribusi Frekuensi Kejadian DBD, Kelompok Umur, Jenis Kelamin, Tingkat Pendidikan, Status Pekerjaan, Pengetahuan, Sikap, Tindakan, Keberadaan Tempat Penampungan Air, dan Keberadaan Jentik Nyamuk pada Masyarakat di RW 06 Kelurahan Ciracas Kecamatan Ciracas Jakarta Timur Tahun 2018

\begin{tabular}{|c|c|c|c|c|c|}
\hline Variabel & $\mathbf{n}$ & $\%$ & Variabel & $\mathbf{n}$ & $\%$ \\
\hline Kejadian DBD & & & Pengetahuan & & \\
\hline Sakit DBD & 17 & 15,9 & Buruk & 9 & 8,4 \\
\hline Tidak sakit DBD & 90 & 84,1 & Baik & 98 & 91,6 \\
\hline Kelompok Umur & & & Sikap & & \\
\hline$<15$ Tahun & 8 & 7,5 & Buruk & 7 & 6,5 \\
\hline$\geq 15$ Tahun & 99 & 92,5 & Baik & 100 & 93,5 \\
\hline Jenis Kelamin & & & Tindakan & & \\
\hline Laki-laki & 20 & 18,7 & Buruk & 14 & 13,1 \\
\hline Perempuan & 87 & 81,3 & Baik & 93 & 86,9 \\
\hline Tingkat Pendidikan & & & Keberadaan Tempat Penampungan Air & & \\
\hline Rendah & 40 & 37,4 & Ada & 107 & 100 \\
\hline Tinggi & 67 & 62,6 & Tidak Ada & 0 & 0 \\
\hline Status Pekerjaan & & & Keberadaan Jentik Nyamuk & & \\
\hline Tidak Bekerja & 85 & 79,4 & Ada & 16 & 15 \\
\hline Bekerja & 22 & 20,6 & Tidak Ada & 91 & 85 \\
\hline
\end{tabular}

Sumber: Data Primer Terolah Tahun 2019

Berdasarkan tabel 1. diketahui bahwa dari 107 masyarakat yang berumur $<15$ tahun tahun sebanyak 8 orang $(7,5 \%)$ di antaranya anak- anak, dan masyarakat yang berumur $>15$ sebanyak 99 orang yaitu remaja, dewasa dan orang tua. Diketahui bahwa dari 107 masyarakat yang berjenis kelamin laki-laki sebanyak 20 orang $(18,7 \%)$, dan berjenis kelamin perempuan sebanyak 87 orang $(81,3 \%)$.

Diketahui bahwa dari 107 masyarakat yang memiliki pendidikan rendah ( $\leq$ SMP) sebanyak 40 orang $(37,4 \%)$ yaitu tidak sekolah, SD dan SMP. Sedangkan masyarakat yang memiliki pendidikan tinggi ( $\geq$ SMA) sebanyak 67 orang $(62,6 \%)$ yaitu SMA dan Perguruan Tinggi. Berdasarkan tabel 1.5. diketahui bahwa dari 107 masyarakat yang tidak bekerja sebanyak 85 orang $(79,4 \%)$ sebagian besar ibu rumah tangga, dan yang bekerja sebanyak 22 orang $(20,6 \%)$ yaitu PNS, TNI, Buruh, Wiraswasta, dan Wirausaha.

Diketahui bahwa dari 107 masyarakat yang memiliki pengetahuan buruk sebanyak 9 orang $(8,4 \%)$ seperti tidak mengetahui penyebab penyakit DBD, waktu nyamuk menggigit dan tempat perindukan nyamuk penyebab DBD. Sedangkan masyarakat yang memiliki pengetahuan baik sebanyak 98 orang
$(91,6 \%)$ dalam hal ini sudah mengetahui pencegahan dan pengendalian penyakit DBD. dari 107 masyarakat yang memiliki sikap mengenai kegiatan PSN buruk sebanyak 7 orang $(6,5 \%)$ dimana masyarakat tidak setuju apabila melakukan PSN secara mandiri, dan tidak setuju apabila PSN lebih efektif dan efisien dibandingkan dengan melakukan fogging. Sedangkan masyarakat yang memiliki sikap mengenai kegiatan PSN baik sebanyak 100 orang $(93,5 \%)$ sudah menyetujui kegiatan PSN.

Diketahui bahwa dari 107 masyarakat yang memiliki tindakan mengenai kegiatan PSN buruk sebanyak 14 orang $(13,1 \%)$ seperti tidak menguras bak mandi dan tampungan dispenser maksimal seminggu sekali, kebiasaan menggantung pakaian, tidak memelihara ikan pemakan jentik, tidak mendaur ulang atau menyingkirkan barang-barang bekas, memiliki kebiasaan menampung air di ember dalam waktu lama, dan tidak memberikan larvasida pada bak air yang sulit dikuras. Sedangkan masyarakat yang memiliki tindakan mengenai kegiatan PSN baik sebanyak 93 orang $(86,9 \%)$ sudah melakukan kegiatan PSN.

Terdapat $100 \%$ rumah memiliki tempat penampungan air antara lain bak mandi, ember, akuarium, dispenser, pembuangan air kulkas 
dan AC, kolam ikan, tempat minum burung, barang-barang bekas, tatakan pot dan drum. Hasil pengamatan terhadap keberadaan jentik Aedes aegypti dari 107 rumah masyarakat sebanyak 16 rumah (15\%) ada jentik Aedes aegypti di RT 01, 02, 04, 05, 06, 08, 09, 010, dan 012. Sedangkan 91 rumah (85\%) tidak ada jentik Aedes aegypti sebagian besar di RT 03, 07, 011, dan 013.

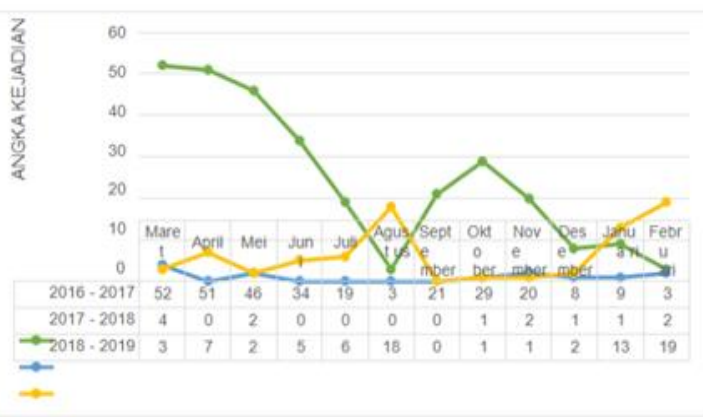

\section{Gambar 1. Distribusi Frekuensi Kejadian Demam Berdarah Dengue Berdasarkan Perbandingan Musim Kemarau dan Musim Hujan di Kelurahan Ciracas Tahun 2016 - 2019}

Berdasarkan gambar 1. menunjukkan bahwa grafik kasus DBD di Kelurahan Ciracas menunjukkan bahwa puncak kejadian DBD pada musim kemarau (Maret - Agustus) di tahun 2016 - 2017 terjadi pada bulan Maret sebesar 52 kasus, di tahun 2017 - 2018 terjadi pada bulan Maret sebesar 4 kasus, dan di tahun 2018 - 2019 terjadi pada bulan Agustus sebesar 18 kasus. Sedangkan, puncak kejadian penyakit DBD pada musim hujan (September - Februari) di tahun 2016 - 2017 terjadi pada bulan Oktober sebesar 29 kasus, di tahun 2017 - 2018 terjadi pada bulan November dan Februari sebesar 2 kasus, dan di tahun 2018 - 2019 terjadi pada bulan Februari sebesar 19 kasus.

Berdasarkan tabel 2. diketahui bahwa masyarakat berumur $<15$ tahun yang sakit DBD sebanyak 8 orang (100\%) dan yang tidak sakit tidak ada, sedangkan masyarakat yang berumur $>15$ tahun yang pernah mengalami sakit DBD sebanyak 9 orang $(9,1 \%)$ dan yang tidak sakit DBD sebanyak 90 orang $(90,9 \%)$.

Berdasarkan hasil uji statistik hubungan antara umur terhadap kejadian DBD didapatkan nilai $p$-value sebesar $0,000 \leq \alpha(0,05)$ maka Ho ditolak, yang berarti ada hubungan yang bermakna antara kelompok umur terhadap kejadian DBD.

Masyarakat berjenis kelamin laki-laki yang sakit DBD sebanyak 7 orang (35\%) dan yang tidak sakit DBD sebanyak 13 orang (65\%), sedangkan masyarakat berjenis kelamin perempuan yang sakit DBD sebanyak 10 orang $(11,5 \%)$ dan yang tidak sakit DBD sebanyak 77 orang $(88,5 \%)$.

Berdasarkan hasil uji statistik hubungan antara jenis kelamin terhadap kejadian DBD didapatkan nilai p-value sebesar $0,017 \leq \alpha$ $(0,05)$ maka Ho ditolak, yang berarti ada hubungan yang bermakna antara jenis kelamin terhadap kejadian DBD di RW 06 Kelurahan Ciracas, Kecamatan Ciracas, Jakarta Timur Tahun 2019. Nilai $\mathrm{OR}=4,146$ artinya masyarakat berjenis kelamin laki - laki memiliki risiko 4,146 lebih besar terkena penyakit DBD dibandingkan masyarakat berjenis kelamin perempuan.

Masyarakat berpendidikan rendah yang sakit DBD sebanyak 10 orang $(25 \%)$ dan yang tidak sakit DBD sebanyak 30 orang (75\%), sedangkan masyarakat berpendidikan tinggi yang sakit DBD sebanyak 7 orang $(10,4 \%)$ dan yang tidak sakit DBD sebanyak 60 orang $(89,6 \%)$.

Berdasarkan hasil uji statistik hubungan antara pendidikan terhadap kejadian DBD didapatkan $\mathrm{p}$-value sebesar $0,086 \geq \alpha(0,05)$ maka Ho gagal ditolak yang berarti tidak ada hubungan yang bermakna antara pendidikan terhadap kejadian DBD.

Berdasarkan tabel 2. diketahui bahwa masyarakat berumur $<15$ tahun yang sakit DBD sebanyak 8 orang $(100 \%)$ dan yang tidak sakit tidak ada, sedangkan masyarakat yang berumur $>15$ tahun yang pernah mengalami sakit DBD sebanyak 9 orang $(9,1 \%)$ dan yang tidak sakit DBD sebanyak 90 orang $(90,9 \%)$. Berdasarkan hasil uji statistik hubungan antara umur terhadap kejadian DBD didapatkan nilai pvalue sebesar $0,000 \leq \alpha(0,05)$ maka Ho ditolak, yang berarti ada hubungan yang bermakna antara kelompok umur terhadap kejadian DBD.

Masyarakat berjenis kelamin laki-laki yang sakit DBD sebanyak 7 orang (35\%) dan yang tidak sakit DBD sebanyak 13 orang $(65 \%)$, sedangkan masyarakat berjenis kelamin perempuan yang sakit DBD sebanyak 10 orang $(11,5 \%)$ dan yang tidak sakit DBD sebanyak 77 orang $(88,5 \%)$. Berdasarkan hasil uji statistik hubungan antara jenis kelamin terhadap 
kejadian DBD didapatkan nilai p-value sebesar $0,017 \leq \alpha(0,05)$ maka Ho ditolak, yang berarti ada hubungan yang bermakna antara jenis kelamin terhadap kejadian DBD di RW 06 Kelurahan Ciracas, Kecamatan Ciracas, Jakarta Timur Tahun 2019. Nilai OR $=4,146$ artinya masyarakat berjenis kelamin laki-laki memiliki risiko 4,146 lebih besar terkena penyakit DBD dibandingkan masyarakat berjenis kelamin perempuan. masyarakat berpendidikan rendah yang sakit DBD sebanyak 10 orang (25\%) dan yang tidak sakit DBD sebanyak 30 orang (75\%), sedangkan masyarakat berpendidikan tinggi yang sakit DBD sebanyak 7 orang $(10,4 \%)$ dan yang tidak sakit DBD sebanyak 60 orang $(89,6 \%)$.

Tabel 2. Umur dan Tanda-Tanda Vital Responden berdasarkan Kelompok

\begin{tabular}{|c|c|c|c|c|c|c|c|c|}
\hline \multirow{3}{*}{ Variabel } & \multicolumn{4}{|c|}{ Kejadian DBD } & \multirow{2}{*}{\multicolumn{2}{|c|}{ Total }} & \multirow{3}{*}{ OR } & \multirow{3}{*}{ P Value } \\
\hline & \multicolumn{2}{|c|}{ Sakit } & \multicolumn{2}{|c|}{ Tidak Sakit } & & & & \\
\hline & $\mathbf{n}$ & $\%$ & n & $\%$ & $\mathbf{n}$ & $\%$ & & \\
\hline \multicolumn{9}{|l|}{ Kelompok Umur } \\
\hline$<15$ Tahun & 8 & 100 & 0 & 0 & 8 & 100 & - & 0,000 \\
\hline$\geq 15$ Tahun & 9 & 9,1 & 90 & 90,9 & 99 & 100 & & \\
\hline Jenis Kelamin & & & & & & & 4,146 & \multirow{3}{*}{0,017} \\
\hline Laki-laki & 7 & 35 & 13 & 65 & 20 & 100 & $(1,339-$ & \\
\hline Perempuan & 10 & 11,5 & 77 & 88,5 & 87 & 100 & $12,843)$ & \\
\hline Tingkat Pendidikan & & & & & & & 2,857 & \multirow{3}{*}{0,086} \\
\hline Rendah & 10 & 25 & 30 & 75 & 40 & 100 & $(0,989-$ & \\
\hline Tinggi & 7 & 10,4 & 60 & 89,6 & 67 & 100 & $8,252)$ & \\
\hline Status Pekerjaan & 13 & 15,3 & 72 & 84,7 & 85 & 100 & 0,813 & \multirow[b]{2}{*}{0,748} \\
\hline $\begin{array}{l}\text { Tidak Bekerja } \\
\text { Bekerja }\end{array}$ & 4 & 18,2 & 18 & 81,8 & 22 & 100 & $\begin{array}{c}(0,237- \\
2,791)\end{array}$ & \\
\hline Pengetahuan & & 44.4 & & & & & 5,231 & \multirow{3}{*}{0,034} \\
\hline Buruk & 13 & 133 & 85 & $\begin{array}{l}8,0 \\
867\end{array}$ & 08 & 100 & $(1,241-$ & \\
\hline Baik & 15 & & 85 & 80,1 & 98 & 100 & $22,045)$ & \\
\hline Sikap & & & & & & & 4,607 & \multirow{3}{*}{0,078} \\
\hline Buruk & 3 & $\begin{array}{c}42,9 \\
14\end{array}$ & $\begin{array}{c}4 \\
86\end{array}$ & $\begin{array}{c}5,1 \\
86\end{array}$ & 100 & 100 & $(0,930-$ & \\
\hline Baik & & & & & & & $22,819)$ & \\
\hline Tindakan & & & & & & & 3,750 & \multirow{3}{*}{0,045} \\
\hline Buruk & 12 & $\begin{array}{l}35,1 \\
129\end{array}$ & $\begin{array}{l}9 \\
81\end{array}$ & $\begin{array}{l}04,3 \\
871\end{array}$ & $\begin{array}{l}14 \\
03\end{array}$ & 100 & $(1,074-$ & \\
\hline Baik & & & & $8 /, 1$ & & & $13,090)$ & \\
\hline \multicolumn{9}{|l|}{ Keberadaan Tempat } \\
\hline Penampungan Air & 17 & 15,9 & 90 & 84,1 & 107 & 100 & & \multirow{3}{*}{-} \\
\hline Ada & 0 & 0 & 0 & 0 & 0 & 0 & & \\
\hline Tidak Ada & & & & & & & & \\
\hline \multicolumn{9}{|l|}{ Keberadaan Jentik } \\
\hline Nyamuk & 3 & 18,8 & 13 & 81,3 & 16 & 100 & $(0,320-$ & \multirow{3}{*}{0,716} \\
\hline Ada & 14 & 15,4 & 77 & 84,6 & 91 & 100 & $5,038)$ & \\
\hline Tidak Ada & & & & & & & & \\
\hline
\end{tabular}

Berdasarkan hasil uji statistik hubungan antara pendidikan terhadap kejadian DBD didapatkan p-value sebesar $0,086 \geq \alpha(0,05)$ maka Ho gagal ditolak yang berarti tidak ada hubungan yang bermakna antara pendidikan terhadap kejadian DBD. masyarakat yang tidak bekerja dan sakit DBD sebanyak 13 orang
$(15,3 \%)$, dan yang tidak sakit DBD sebanyak 72 orang $(84,7 \%)$, sedangkan masyarakat yang bekerja dan sakit DBD sebanyak 4 orang $(18,2 \%)$, dan yang tidak sakit DBD sebanyak 18 orang $(81,8 \%)$. Berdasarkan hasil uji statistik hubungan antara pekerjaan terhadap kejadian DBD didapatkan hasil $\mathrm{p}$-value sebesar $0,748 \geq$ 
$\alpha(0,05)$ maka Ho gagal ditolak, yang berarti tidak ada hubungan antara status pekerjaan terhadap kejadian DBD di RW 06 Kelurahan Ciracas, Kecamatan Ciracas, Jakarta Timur Tahun 2019.

Masyarakat berpengetahuan buruk mengenai kegiatan PSN yang sakit DBD sebanyak 4 orang $(44,4 \%)$ dan yang tidak sakit DBD sebanyak 5 orang $(55,6 \%)$, sedangkan masyarakat berpengetahuan baik yang sakit DBD sebanyak 13 orang $(13,3 \%)$ dan yang tidak sakit DBD sebanyak 90 orang $(84,1 \%)$. Berdasarkan hasil uji statistik hubungan antara pengetahuan masyarakat mengenai kegiatan PSN terhadap kejadian DBD didapatkan nilai pvalue sebesar $0,034 \leq \alpha(0,05)$ maka Ho ditolak, yang berarti ada hubungan yang bermakna antara pengetahuan masyarakat mengenai kegiatan PSN terhadap kejadian DBD di RW 06 Kelurahan Ciracas, Kecamatan Ciracas, Jakarta Timur Tahun 2019. Nilai OR $=5,231$ artinya masyarakat yang memiliki pengetahuan buruk mengenai kegiatan PSN DBD memiliki risiko 5,231 kali lebih besar terkena penyakit DBD dibandingkan masyarakat yang memiliki pengetahuan baik mengenai kegiatan PSN.

Masyarakat bersikap buruk mengenai kegiatan PSN yang sakit DBD sebanyak 3 orang $(42,9 \%)$ dan yang tidak sakit sebanyak 4 orang $(57,1 \%)$, sedangkan masyarakat yang bersikap baik mengenai kegiatan PSN yang sakit DBD sebanyak 14 orang (14\%) dan yang tidak sakit DBD sebanyak 86 orang (86\%). Berdasarkan hasil uji statistik hubungan antara sikap masyarakat mengenai kegiatan PSN terhadap kejadian DBD didapatkan nilai $\mathrm{p}$ value sebesar $0,078 \geq \alpha(0,05)$ maka Ho gagal ditolak, yang berarti tidak ada hubungan antara sikap masyarakat mengenai kegiatan PSN terhadap kejadian DBD di RW 06 Kelurahan Ciracas, Kecamatan Ciracas, Jakarta Timur Tahun 2019.

Masyarakat yang memiliki tindakan buruk mengenai kegiatan PSN yang sakit DBD sebanyak 5 orang $(35,7 \%)$ dan yang tidak sakit sebanyak 9 orang $(64,3 \%)$, sedangkan masyarakat yang memiliki tindakan baik mengenai kegiatan PSN yang sakit DBD sebanyak 12 orang $(12,9 \%)$ dan yang tidak sakit DBD sebanyak 81 orang $(87,1 \%)$. Berdasarkan hasil uji statistik hubungan antara tindakan masyarakat mengenai kegiatan PSN terhadap kejadian DBD didapatkan nilai $\mathrm{p}$-value sebesar $0,045 \leq \alpha(0,05)$ maka Ho ditolak, yang berarti ada hubungan yang bermakna antara tindakan masyarakat mengenai PSN terhadap kejadian DBD di RW 06 Kelurahan Ciracas, Kecamatan Ciracas, Jakarta Timur Tahun 2019. Nilai OR = 3,740 artinya masyarakat yang memiliki tindakan buruk mengenai kegiatan PSN memiliki risiko 3,740 kali lebih besar terkena penyakit DBD dibandingkan masyarakat yang memiliki tindakan baik mengenai kegiatan PSN.

Seluruh masyarakat (100\%) memiliki Tempat Penampungan Air (TPA) sehingga tidak bisa dilakukan uji hubungan antara keberadaan Tempat Penampungan Air (TPA) terhadap kejadian DBD di RW 06 Kelurahan Ciracas, Kecamatan Ciracas, Jakarta Timur. masyarakat yang rumahnya ada jentik Aedes aegypti dan sakit DBD sebanyak 3 orang $(18,8 \%)$, dan yang tidak sakit DBD sebanyak 13 orang $(81,3 \%)$, sedangkan masyarakat yang rumahnya tidak ada jentik Aedes aegypti dan sakit DBD sebanyak 14 orang $(15,4 \%)$, dan yang tidak sakit DBD sebanyak 90 orang $(84,1 \%)$. Berdasarkan hasil uji statistik hubungan antara keberadaan jentik terhadap kejadian DBD didapatkan nilai p-value sebesar $0,716 \geq \alpha(0,05)$ maka Ho gagal ditolak, yang berarti tidak ada hubungan yang bermakna antara keberadaan jentik nyamuk di RW 06 Kelurahan Ciracas, Kecamatan Ciracas, Jakarta Timur Tahun 2019.

\section{PEMBAHASAN}

\section{Hubungan Kelompok Umur dengan Kejadian DBD}

Penyakit demam berdarah dengue pada dasarnya tidak menyerang pada kelompok umur tertentu tetapi dapat menyerang semua umur baik anak-anak maupun orang dewasa (Hidayat, 2017). Berdasarkan hasil uji statistik hubungan antara kelompok umur terhadap kejadian DBD didapatkan nilai p-value sebesar $0,000 \leq \alpha$ $(0,05)$ maka Ho ditolak, yang berarti ada hubungan yang bermakna antara kelompok umur terhadap kejadian DBD.

Hasil penelitian ini sejalan dengan penelitian Sunarsih yang menunjukkan bahwa terdapat hubungan antara umur dengan kejadian DBD di wilayah kerja Puskesmas Tlogosari Wetan (Sunarsih, 2017). Penelitian ini menunjukkan bahwa kelompok umur $<15$ tahun yaitu anak-anak lebih dominan terkena penyakit DBD. Hal ini disebabkan karena sistem kekebalan tubuh pada anak-anak masih rendah 
sehingga rentan terhadap penyakit, dan aktivitas anak- anak lebih banyak di luar rumah seperti pada pagi hari mereka lebih banyak menghabiskan waktu di sekolah atau bermain selama beberapa jam atau bahkan hampir seharian di dalam kondisi dan waktu untuk terkena risiko gigitan nyamuk penular DBD.

Dengan demikian, kelompok umur $<15$ tahun atau anak-anak perlu mendapatkan prioritas perlindungan dari penularan penyakit DBD. Misalnya kegiatan Pemberantasan Sarang Nyamuk diutamakan rumah yang di dalamnya terdapat anak- anak, dan meningkatkan status gizi anak agar daya tahan tubuh jadi lebih kuat.

\section{Hubungan Jenis Kelamin dengan Kejadian DBD}

Penyakit menular sebagian besar menyerang semua jenis kelamin. Perbedaan prevalensi antara laki-laki dan wanita biasanya disebabkan oleh gaya hidup (Wardhani, Martini, \& Ua, 2015). Hasil uji statistik hubungan antara jenis kelamin terhadap kejadian DBD didapatkan nilai p-value $0,017 \leq$ $\alpha(0,05)$ maka Ho ditolak, yang berarti ada hubungan yang bermakna antara jenis kelamin terhadap kejadian DBD di RW 06 Kelurahan Ciracas, Kecamatan Ciracas, Jakarta Timur Tahun 2019. Nilai OR $=4,146$ artinya masyarakat berjenis kelamin laki-laki memiliki risiko 4,146 lebih besar terkena penyakit DBD dibandingkan masyarakat berjenis kelamin perempuan.

Adanya hubungan antara jenis kelamin terhadap kejadian DBD ini dikarenakan menurut teori Halstead dalam Guha-Sapir \& Schimmer (2005) menyatakan bahwa jumlah penderita DBD yang berjenis kelamin laki-laki lebih banyak daripada perempuan karena faktor imunitas di dalam tubuh. Perempuan memiliki respon imun yang lebih baik daripada respon imun yang dimiliki oleh laki- laki. Hal ini dikarenakan produksi cytokine pada perempuan lebih besar daripada pada laki-laki. Cytokine ini merupakan hormon yang bertanggungjawab dalam pengaturan intensitas dan durasi respon imun dalam tubuh seseorang. Selain itu lakilaki juga memiliki mobilitas dan aktivitas pekerjaan yang cenderung tinggi sehingga bisa saja laki laki melakukan perjalanan ke daerah yang endemis DBD.

Dengan demikian, sebaiknya masyarakat melakukan perlindungan diri terhadap gigitan nyamuk seperti menggunakan lotion anti nyamuk ketika bepergian di daerah endemis DBD maupun tidak serta menggunakan obat anti nyamuk seperti obat nyamuk semprot/aerosol, bakar dan elektrik.

\section{Hubungan Tingkat Pendidikan dengan Kejadian DBD}

Pendidikan berkaitan dengan pengetahuan seseorang. Salah satu tujuan pendidikan adalah memberikan dan meningkatkan pengetahuan sehingga dicapai suatu masyarakat yang berkembang yang pada akhirnya menuju suatu perubahan perilaku (Umar, 2015).

Hasil penelitian ini sejalan dengan penelitian Ardani, menunjukkan bahwa tidak ada hubungan antara pendidikan terhadap kejadian DBD di wilayah kerja Puskesmas Harapan Jaya Tahun 2018 (Ardianti, 2018). Penelitian ini juga sejalan dengan penelitian yang dilakukan oleh Handoyo yang mengatakan bahwa tidak ada hubungan antara tingkat pendidikan dengan kejadian DBD di Pesisir Pantai Kota Tarakan (Wahyu Handoyo, 2015).

Tidak adanya hubungan antara tingkat pendidikan terhadap kejadian DBD dikarenakan pengetahuan dan informasi mengenai penyebab, gejala dan tanda, dampak atau akibat, pencegahan dan pengendalian penyakit DBD bisa didapatkan dari mana saja, seperti sosial media, televisi, koran, radio dan lain-lain sehingga masyarakat tidak harus memiliki pendidikan yang tinggi untuk memperoleh informasi dan pengetahuan tentang DBD.

\section{Hubungan Status Pekerjaan dengan Kejadian DBD}

Hasil penelitian ini sejalan dengan penelitian Monintja, menunjukkan bahwa tidak ada hubungan antara pekerjaan terhadap kejadian DBD di Kelurahan Malalayang I Kecamatan Malalayang Kota Manado (Monintja, 2015). Tidak adanya hubungan antara Status pekerjaan terhadap kejadian DBD berkaitan dengan responden di RW 06 Kelurahan Ciracas, Kecamatan Ciracas, Jakarta Timur dimana rata-rata pekerjaan mereka yaitu buruh, wiraswasta, PNS maupun wirausaha yang pada umumnya lingkungan kerja mereka tidak jauh berbeda dengan lingkungan di rumah.

Penyebaran vektor penyebab DBD hampir merata di seluruh tempat sehingga baik orang yang tidak bekerja maupun bekerja 
memiliki kemungkinan yang hampir sama untuk terkena penyakit DBD, kecuali pada orang-orang yang bekerjanya sebagai petani di sawah ataupun di kebun yang rindang dapat pula berisiko terkena gigitan nyamuk Aedes albopictus yang juga termasuk vektor penyakit DBD, karena pada umumnya nyamuk ini lebih suka tinggal di semak-semak dan di kebun yang rindang.

\section{Hubungan Pengetahuan Masyarakat mengenai Kegiatan PSN dengan Kejadian Demam Berdarah Dengue}

Pengetahuan merupakan hasil dari tahu dan ini terjadi setelah seseorang melakukan pengindraan terhadap suatu objek tertentu. Pengetahuan adalah hal apa yang diketahui oleh orang atau responden terkait sehat dan sakit atau kesehatan, misalnya tentang penyakit (penyebab, cara penularan, dan cara pencegahan). Hasil penelitian ini sejalan dengan penelitian Lirin, menunjukkan bahwa ada hubungan yang signifikan antara tingkat pengetahuan masyarakat dengan kejadian DBD Di Kerja Puskesmas Kayen Kabupaten Pati (L. Novitasari, 2018).

Pada penelitian ini menunjukkan adanya hubungan antara pengetahuan terhadap kejadian DBD ini didukung oleh hasil tabulasi silang yang menyimpulkan bahwa masyarakat yang mempunyai pengetahuan baik tentang PSN dan tidak sakit DBD lebih banyak yaitu sebanyak 87 orang (86,7\%). Menurut Kusumawardani dalam hal ini dikarenakan kesempatan mendapatkan informasi tentang DBD dari petugas kesehatan ketika penderita sedang menjalani pengobatan di pusat pelayanan kesehatan. Maka, informasi dari petugas kesehatan atau kader puskesmas bisa menjadi sarana bagi penderita dan masyarakat untuk meningkatkan pengetahuan terkait DBD sehingga dapat menurunkan risiko DBD.

Informasi tentang DBD dan kegiatan PSN diperoleh baik dari pengalaman langsung maupun dari pengalaman orang lain. Apabila seseorang memiliki pengetahuan tentang kesehatan yang baik, maka orang itu akan berusaha menghindari atau meminimalisir terjadinya suatu penyakit seperti melakukan kegiatan PSN 3M Plus.

Masyarakat dengan pengetahuan buruk dan sakit DBD sebagian besar belum mengetahui tentang penyebab penyakit DBD, masyarakat dengan pengetahuan buruk banyak yang tidak mengetahui apa penyebab penyakit DBD, sehingga ketika diwawancara mengenai penyebab penyakit DBD terlihat kebingungan. Mereka beranggapan bahwa mereka tidak pernah terkena sakit DBD sehingga tidak tahu apa penyebab penyakit DBD.

Waktu nyamuk Aedes aegypti menggigit, masyarakat lebih banyak menjawab waktu nyamuk Aedes aegypti menggigit adalah setiap waktu, karena menurut mereka nyamuk bisa ditemukan dan menggigit manusia setiap waktu. Ketidaktahuan masyarakat mengenai waktu nyamuk Aedes aegypti menggigit dapat berisiko terkena penyakit DBD, maka dari itu dengan mengetahui kapan nyamuk Aedes aegypti menggigit masyarakat akan lebih waspada.

Tempat perindukan nyamuk penyebab DBD, masyarakat beranggapan bahwa tempat perindukan nyamuk penyebab DBD adalah dimana saja, termasuk pada empang, comberan, parit dengan air yang kotor, karena responden tidak mengetahui tempat perindukan nyamuk Aedes aegypti. Ketidaktahuan masyarakat akan tempat perindukan nyamuk yang benar hal ini berisiko terhadap keberadaan breeding place (tempat perindukkan) yang memberikan pengaruh cukup signifikan terhadap keberadaan jentik Aedes aegypti dan kejadian DBD.

Masyarakat yang tidak mengetahui kegiatan PSN dapat mempengaruhi tindakan yang akan dilakukan sehingga tindakan yang dilakukan kurang tepat. Oleh karena itu, pentingnya untuk memiliki pengetahuan yang baik dan terus mencari informasi untuk menambah pengetahuan terkait DBD, karena dengan pengetahuan yang baik maka seseorang akan mampu melakukan suatu tindakan yang baik pula dan menciptakan lingkungan yang baik, sehingga diharapkan dapat mencegah dan memutus rantai penularan penyakit DBD. Serta perhatian khusus dari pemerintah juga sangat diperlukan untuk menanggulangi kasus DBD yang selalu endemis setiap tahun di berbagai wilayah agar tidak menyebar luas ke daerahdaerah lainnya sehingga kejadian DBD dapat diminimalisir sedini mungkin (Kusumawardani \& Achmadi, 2012).

Hubungan Sikap Masyarakat Mengenai Kegiatan PSN dengan Kejadian Demam Berdarah Dengue

Pengertian sikap merupakan reaksi atau respons yang masih tertutup dari seseorang 
terhadap suatu stimulus atau objek. Hasil penelitian ini tidak sejalan dengan penelitian Monintja, yang menunjukkan bahwa ada hubungan antara sikap dengan kejadian DBD di Wilayah Kerja Puskesmas Ranotana Weru Kota Manado (Monintja, 2015).

Masyarakat sebagian besar sudah bersikap baik terhadap kegiatan PSN di antaranya setuju apabila kegiatan PSN dilakukan secara serentak dan terus menerus, setuju apabila kegiatan PSN merupakan tanggung jawab bersama antara pemerintah dan masyarakat, setuju apabila kegiatan PSN harus terus dilakukan walaupun tidak ada kasus DBD dan sedikit sekali responden yang tidak setuju terhadap kegiatan PSN seperti tidak setuju apabila melakukan PSN secara mandiri, dan tidak setuju apabila PSN lebih efektif dan efisien dibandingkan dengan melakukan fogging. Namun di sekitar rumah masyarakat masih banyak ditemukan jentik, hal ini dikarenakan sikap merupakan kecenderungan untuk bertindak tetapi belum tentu terwujud dalam tindakan, maka dari itu untuk mewujudkan suatu tindakan perlu faktor lain seperti faktor pendorong atau faktor penguat (reinforcing factors)(Pangemanan, 2012).

Dalam hal ini peran petugas kesehatan dan jumantik sebagai faktor pendorong perlu ditingkatkan lagi dalam melakukan kegiatan PSN dan menyebarkan informasi kepada masyarakat secara menyeluruh dimana petugas kesehatan dan kader jumantik diperlukan sebagai fasilitator agar sikap masyarakat agar sikap masyarakat yang sudah setuju terhadap kegiatan PSN dapat ditingkatkan menjadi perilaku terbuka (tindakan) serta perlu adanya upaya penyadaran sikap bahwa siapa pun mempunyai risiko yang sama untuk terserang penyakit DBD.

\section{Hubungan Tindakan Masyarakat Mengenai Kegiatan PSN dengan Kejadian DBD}

Hasil penelitian ini sejalan dengan

penelitian Aryati (2012) (34) yang menunjukkan bahwa ada hubungan antara tindakan dengan kejadian DBD di Kelurahan Baler Bale Agung Kecamatan Negara (Aryati, 2012). Adanya hubungan antara tindakan masyarakat terhadap kegiatan PSN terhadap kejadian DBD dikarenakan dari hasil penelitian masyarakat menganggap lingkungan sudah bersih sehingga kegiatan PSN 3M Plus diabaikan dalam pencegahan DBD.
Responden dengan tindakan buruk sebagian besar belum melaksanakan tindakan seperti tidak rutin menguras bak mandi dan tampungan dispenser maksimal seminggu sekali. Berdasarkan hasil observasi masih ditemukan responden yang tidak menguras bak mandi maksimal seminggu sekali dan bak mandinya pun terlihat kotor. Hal ini dikarenakan kamar mandi yang terdapat bak mandi tersebut jarang digunakan, hanya dikuras ketika terlihat kotor saja, dan kurangnya pemantauan dari anggota keluarga. Jika dilihat dari siklus hidup nyamuk Aedes aegypti telur yang sudah menetas menjadi jentik akan mengalami stadium jentik selama 6-8 hari, maka bak mandi yang tidak di kuras rutin setiap seminggu sekali berpotensi menjadi tempat berkembangnya jentik hingga menjadi nyamuk dewasa. Begitu pula dengan tampungan dispenser yang diperiksa kondisinya kotor dan terdapat jentik.

Kebiasaan menggantung pakaian. Berdasarkan hasil observasi ditemukan sebagian masyarakat masih menggantung pakaian di dalam rumah. Pakaian bekas pakai yang tergantung di dalam rumah, merupakan media yang disenangi nyamuk penular DBD, yang merupakan salah satu faktor risiko yang meningkatkan terjadinya penyakit DBD. Menurut (Biu \& Hassan, 2012) yang nyamuk Aedes aegypti menggigit pada siang hari di tempat yang agak gelap. Pada malam hari, nyamuk ini bersembunyi di sela-sela pakaian yang tergantung di dalam kamar yang gelap dan lembap.

Tidak memelihara ikan pemakan jentik. Berdasarkan hasil observasi ditemukan bahwa beberapa masyarakat tidak memelihara ikan pemakan jentik di kolam yang sudah tidak terpakai namun terdapat air di dalamnya dan tidak pernah dilakukan pengurasan.

Tidak mendaur ulang atau menyingkirkan barang-barang bekas. Hal ini dikarenakan sebagian masyarakat hanya menunggu barang-barang bekas tersebut diambil/diangkut oleh petugas kebersihan. Kebiasaan tidak menyingkirkan atau mendaur ulang barang bekas seperti ban bekas, botol, plastik dan barang-barang lain yang dapat menampung air sehingga menyebabkan bertambahnya tempat perindukan nyamuk Aedes aegypti dan akan mengakibatkan perkembangbiakan nyamuk tersebut meningkat 
dan risiko terjadinya kejadian DBD semakin besar.

Kebiasaan menampung air di ember dalam waktu lama. Air yang dibiarkan lama di ember tentu saja dapat menjadi tempat berkembangnya jentik Aedes aegypti. Menurut (36) Semakin banyak tempat-tempat penampungan air akan semakin banyak tempat perindukan dan akan semakin padat populasi nyamuk Aedes aegypti.

Tidak memberikan bubuk abate pada tempat penampungan air yang sulit dikuras seperti tandon air, dikarenakan terkadang pihak kader tidak memberikan bubuk abate kepada warga saat melakukan kegiatan PSN. hal ini akan mengakibatkan perkembangbiakan nyamuk tersebut meningkat dan risiko terjadinya kejadian DBD semakin besar.

Oleh karena itu, masyarakat harus terus mengupayakan tindakan yang baik dalam mencegah DBD dengan cara melakukan PSN $3 \mathrm{M}$ Plus secara rutin, mencari informasi terkait pentingnya tindakan pencegahan DBD, sehingga nantinya dapat mengajak orang lain maupun anggota keluarga untuk bertindak baik mengenai kegiatan PSN 3M Plus.

\section{Hubungan Keberadaan Tempat Penampungan Air dengan Kejadian Demam Berdarah Dengue}

Dari hasil penelitian yang dilakukan diketahui bahwa semua responden memiliki Tempat Penampungan Air (data homogen), sehingga tidak bisa dilakukan uji hubungan. Hal ini dikarenakan sistem penyediaan air di masyarakat bermacam-macam baik melalui perpipaan maupun sumber lain seperti sumur gali dan lain-lain, sehingga masih memerlukan tempat penampungan air seperti bak mandi, ember besar maupun kecil dan lain-lain.

Tempat penampungan air merupakan media untuk berkembang biak nyamuk Aedes aegypti, maka dari itu untuk menghindari agar nyamuk tidak meletakkan telur-telurnya pada penampungan air sebaiknya melakukan pengurasan tempat penampungan air maksimal seminggu sekali sehingga telur nyamuk tidak dapat berkembang menjadi nyamuk dewasa yang siap menularkan virus dengue serta melakukan penaburan bubuk abate di tempattempat yang sulit untuk dikuras.

\section{Hubungan Keberadaan Jentik Nyamuk dengan Kejadian DBD}

Hasil penelitian ini sejalan dengan penelitian Yunita yang menunjukkan bahwa tidak ada hubungan antara keberadaan jentik dengan kejadian DBD di Provinsi Riau (Yunita et al., 2012). Tidak adanya hubungan antara keberadaan jentik terhadap kejadian DBD ini karena responden menyadari bahaya penyakit DBD dan sudah mulai melakukan kegiatan 3M Plus yaitu Menguras, Menutup, dan Mendaur ulang barang-barang bekas serta kegiatan Plus nya yaitu menggunakan obat anti nyamuk, menaburkan larvasida di tempat yang sulit untuk dikuras, melakukan kegiatan kerja bakti di lingkungan sekitar rumah, dan memantau semua wadah air atau yang dapat menampung air secara rutin.

Namun, berdasarkan hasil penelitian menunjukkan bahwa Angka Bebas Jentik (ABJ) sebesar $85,04 \%$. Hal ini masih berada di bawah batas aman yang ditetapkan oleh WHO dan Kementerian Kesehatan (ABJ >95\%). House Index (HI) sebesar 15\% masih melebihi standar yang ditetapkan oleh WHO yaitu sebesar $<10 \%$, Container Index (CI) sebesar 6,7\% juga masih melebihi standar yang ditetapkan oleh WHO yaitu sebesar $<5 \%$, sedangkan Breteau Index (BI) sebesar $22,4 \%$ sudah memenuhi standar WHO yaitu sebesar $<50 \%$. Berdasarkan keseluruhan angka tersebut didapatkan nilai Density Figure (DF) adalah 4, yang menunjukkan bahwa risiko penularan Demam Berdarah Dengue (DBD) di RW 06 Kelurahan Ciracas, Kecamatan Ciracas, Jakarta Timur termasuk ke dalam kategori sedang yang berarti penularan penyakit DBD masih berpotensi terjadi.

Dengan demikian, sebaiknya masyarakat menerapkan kegiatan satu rumah satu jumantik sehingga melibatkan seluruh keluarga untuk memantau keberadaan jentik di dalam maupun di luar rumah serta melakukan kegiatan PSN 3M Plus lainnya secara terus menerus walaupun sedang tidak ada kasus DBD.

\section{KESIMPULAN DAN SARAN}

Terdapat hubungan yang bermakna antara kelompok umur ( $\mathrm{p}$-value $=0,000)$, jenis kelamin $(\mathrm{p}$-value $=0,017$, OR $=4,146)$, pengetahuan ( $\mathrm{p}$-value $=0,034, \mathrm{OR}=5,231)$, dan tindakan ( $\mathrm{p}$-value $=0,045, \mathrm{OR}=3,740)$ dengan kejadian DBD (p-value $=0,000)$. Seluruh masyarakat (100\%) memiliki Tempat Penampungan Air (TPA) sehingga tidak bisa 
dilakukan uji hubungan antara keberadaan Tempat Penampungan Air (TPA) terhadap kejadian DBD.

Disarankan kepada Masyarakat agar dapat ikut serta secara aktif dalam program PSN DBD melalui perubahan sikap dan peningkatan pengetahuan tentang DBD sehingga dapat melakukan kegiatan PSN 3M Plus secara rutin dan berkesinambungan. Melakukan optimalisasi penyuluhan atau sosialisasi mengenai upaya pencegahan DBD dan menyelenggarakan penyuluhan ketika sedang melakukan PSN ke setiap rumah maupun saat acara kumpul warga.

Bagi Puskesmas meningkatkan kegiatan penyuluhan atau promosi tentang PSN 3M Plus dan program satu rumah satu jumantik seperti penyebaran larvasida secara menyeluruh dan rutin, pemasangan baliho atau stiker tentang DBD, dan atau penyebaran pamflet. Membekali jumantik dengan media penyuluhan seperti buku panduan, atau brosur yang merupakan salah satu faktor Enabling.

\section{DAFTAR PUSTAKA}

Ardianti, W. (2018). Determinan Kejadian Demam Berdarah Dengue (DBD) Di Wilayah Kerja Puskesmas Harapan Raya, 9(1).

Aryati, I. K. (2012). Masyarakat Dengan Kejadian Demam Berdarah Dengue (DBD) Di Kelurahan Baler Bale Agung.

Biu, F. M., \& Hassan, M. S. (2012). Waktu Aktivitas Menghisap Darah Nyamuk Aedes Aegypti Dan Aedes Albopictus Di Desa Pa' Lanassang Kelurahan Barombong Makassar Sulawesi Selatan Period Of Sucking Activity Of Aedes Aegypti And Aedes Albopictus Mosquito At $\mathrm{Pa}$ ' Lanassang Village Barombong Di.

BPPSMK Kementerian Kesehatan. (2018). Metodologi Penelitian Kesehatan Bahan Ajar Rekam Medis dan Informasi Kesehatan.

Candra, A. (2010). Demam Berdarah Dengue: Epidemiologi, Patogenesis, dan Faktor Risiko Penularan Dengue Hemorrhagic Fever: Epidemiology, Pathogenesis , and Its Transmission Risk Factors, 2(2), 110-119.

Febriani, W. (2016). Faktor Yang Mempengaruhi Perubahan Perilaku Stop Buang Air Besar Sembarangan (BABS):
Studi Pada Program Stbm Di Desa Sumbersari Metro Selatan 2016, 5, 121130.

Guerra, C., \& Barbacid, M. (2013). Genetically engineered mouse models of pancreatic adenocarcinoma, 7 .

Hidayat. (2017). Faktor yang Berhubungan dengan Kejadian DBD Di Pulau Balang Lompo Kabupaten Pangkep, 17(Ii), 7381.

Istiqomah. (2017). Hubungan Sikap Caring Perawat dengan Oral Higiene Pada Pasien Stroke Berbasis Teori Swansondi Ruang Flamboyan, RSUD Jombang.

Juwita, C. P. (2020). Variabilitas Iklim dengan Kejadian Demam Berdarah Dengue di Kota Tangerang, 3(1), 8-14.

Kementerian Kesehatan. (2016). infodatin-dbd2016.pdf.

Kementerian Kesehatan RI. (2017). InfoDatinSituasi-Demam-Berdarah-Dengue.pdf.

Kusumawardani, E., \& Achmadi, U. F. (2012). Demam Berdarah Dengue di Perdesaan Dengue Hemorraghic Fever in Rural.

Litbangkes. (2016). Pengetahuan dan Perilaku Masyarakat dalam Pencegahan Demam Berdarah Dengue di Provinsi Jawa Barat dan Kalimantan Barat, 8(November 2015), 69-76.

Meteorologi, B., Geofisika, D. A. N., Nal, D. O., \& Sopl, P. (2019). Badan meteorologi, klimatologi, dan geofisika, (2).

Monintja, T. C. N. (2015). Hubungan Antara Karakteristik Individu, Pengetahuan Dan Sikap Dengan Tindakan PSN DBD Masyarakat Kelurahan Malalayang I Kecamatan Malalayang Kota Manado Relationship Between Individual Characteristic , Knowledge , Attitude With PSN DBD Behavior Of Commun, 503-519.

Nani. (2017). Hubungan perilaku psn dengan keberadaan jentik aedes aegypti di pelabuhan pulang pisau, (January 2017). https://doi.org/10.20473/jbe.v5i1.2017.112

Novitasari, E. (2018). Gambaran Kader Enzim Aspartat Aminotransperase (AST) dan Alamin AminoStransferase (ALT) Pada Pasien Rawat Inal Penderita Deman Berdarah Dengue di RSU Bahteramas Provinsi Sulawesi tenggara, 2(1), 33-40. 
Novitasari, L. (2018). Hubungan Faktor Host, Faktor Lingkungan, Dan Status Gizi Dengan Kejadian Demam Berdarah Dengue Di Wilayah Kerja Puskesmas Kayen Kabupaten Pati, 6, 277-284.

Pangemanan, J. (2012). Perilaku Masyarakat Tentang Program Pemberantasan Penyakit DBD di Kabupaten Minahasa Utara Jane Pangemanan*, Jeini Nelwan* *Fakultas Kesehatan Masyarakat Universitas Sam Ratulangi Manado, 4550.

Prasetyowati, A., \& Kushartanti, R. (2019). Dengue di Wilayah Kerja Puskesmas Rowosari, 02(November), 23-29.

Purnama, S. G. (2017). Pengendalian vektor.

Sari, R., Utami, B., \& Ua, F. K. M. (2014). Hubungan Pengetahuan dan Tindakan Masyarakat dengan Kejadian Demam Berdarah Dengue (DBD) (Studi di Kelurahan Putat Jaya Surabaya Tahun 2010-2014), 242-253.

Sunarsih, N. (2017). Hubungan Faktor Ekologi dan Sosiodemografi Dengan Kejadian DBD (Studi Kasus Diwilaya Kerja Puskesmas Tlogasari Wetan, 2(5).
Umar, H. J. (2015). Peningkatan kualitas pendidikan dan pembangunan kultur global, 15, 167-192.

Wahyu Handoyo. (2015). Hubungan Sosiodemografi Dan Lingkungan Fisik Dengan Kejadian Demam Berdarah Degue (DBD) Pada Masyarakat Pesisir Pantai Kota Tarakan, 3(April), 186-195.

Wardhani, I. O., Martini, S., \& Ua. (2015). Hubungan Antara Karakteristik Pasien Stroke Dan Dukungan Keluarga Dengan Kepatuhan Menjalani Rehabilitasi, 2434.

Yunita, J., Susmaneli, H., Studi, P., Ilmu, M., Masyarakat, K., Hang, S., \& Pekanbaru, T. (2012). Pengaruh Perilaku Masyarakat dan Kondisi Lingkungan Terhadap Kejadian Demam Berdarah Dengue The Influence of Community Behaviour and Environmental Conditions to Dengue Hemorrhagic Fever, 1(05), 0-5.

Yusuf, B., \& Aziizu, A. (2010). 46 tujuan besar pendidikan adalah tindakan, 295-300. 